\title{
Influence of roasted and unroasted terebinth (Pistacia terebinthus) on the functional, chemical and textural properties of wire-cut cookies
}

\author{
Mehmet KÖTEN ${ }^{1 *}$ []
}

\begin{abstract}
The study aimed to access the effects of roasted and unroasted terebinth $(0,10,20,30,40$, and $50 \%)$ added to cookies to improve their physical, chemical, functional, and textural characteristics. The addition of terebinth to the cookie formulation significantly increased the ash, protein, fat, total dietary fiber, total phenolic matter, and antioxidant content and decreased the phytic acid content of the cookie samples. With the addition of roasted and unroasted terebinth, it was determined that $\mathrm{L}^{\star}, \mathrm{b}^{\star}$ values of cookies decreased, $\mathrm{a}^{*}$ value increased, and all color values were lower than control group. In addition, it was found that the diameter and thickness values of cookies with terebinth addition decreased, and the spread ratio increased. The hardness of cookies produced in the study decreased after terebinth addition. The data obtained in this study showed that using terebinth has potential applications in baked goods without adverse effects on the physical and chemical quality or the functional quality of the product.
\end{abstract}

Keywords: cookie; texture; terebinth (Pistacia terebinthus); functional food.

Practical Application: Terebinth is one of the important plant species in terms of its chemical properties and has recently been reported to be a plant rich in antioxidant properties, phenolic content, fat content, fatty acid components, and tocopherol content. In this study, terebinth was added to cookie formulation in from $10-50 \%$ ratios, and its effects on the physical, chemical, functional, and textural properties of the cookie were evaluated.

\section{Introduction}

Cookie is a bakery product obtained by processing, shaping, baking, and adding raising agents into the flour along with sugar, salt, oil, food products, and one or more of the other substances allowed by regulations. The cookie is widely consumed among bakery products because of its practicality, good nutritional quality, and cheapness. Cookies have an important place among snacks because they can last for a long time without spoiling, they appeal to the taste of the consumer, they can be presented in different flavors, and they can be consumed as a snack when the three regular meals provide insufficient nutrients (Demirel \& Demir, 2018; Kolawole et al., 2018).

Changing nutritional habits toward the consumption of more fruits, vegetables, and cereals is an effective and practical approach to the prevention of chronic diseases. In recent years, it has been scientifically demonstrated that the intake of certain foods through "natural" means prevents or cures some diseases (Coşkun, 2005). Today, consumers' preferences for a healthier lifestyle incline towards low-calorie, high-fiber foods with low sugar and salt content and fewer additives (Demir, 2015). The enrichment of cookie formulations that are consumed by particularly by children but are also appealing to adults in the form of snack food is very important because it will ensure that these components are taken into the body during consumption (Doğan \& Meral, 2016).

Terebinth is one of the important plant species in terms of its chemical properties. Terebinth has recently been reported to be a plant rich in antioxidant properties, phenolic content, fat content, fatty acid components, and tocopherol content (Couladis et al., 2003; Topçu et al., 2007; Özcan et al., 2009; Dalgıç et al., 2011). In addition, some studies focused on the chemical properties of terebinth in terms of medicine have highlighted and supported the use of this plant in folk medicine (Özcan et al., 2009; Bakirel et al., 2003; Giner-Larza et al., 2001). Pistacia terebinthus L., commonly known as terebinth, is an oleiferous fruit with a specific flavor and high aroma value and is collected from trees or shrubs found in forested areas in August-October in the Mediterranean region, and is traded in markets, herbalists, and in spice stores.

In Turkey, the terebinth tree is not culturally cultivated, but its fruit is traditionally processed and consumed in unroasted or roasted form in various ways from beverages to pastes (Karakaş \& Certel, 2004). It has been shown that the dry fruit extracts of $P$. terebinthus L. have some hypolipidemic effects without causing toxic effects in rabbits (Bakirel et al., 2003). It has been found that the fruits of P. terebinthus L. improved the lipid profile and caused reductions in atherosclerosis (Edwards et al., 1999). Epilupeol and epilupeol acetate found in the resin of the Pistacia species have been observed to have antiviral activity (Özçelik et al., 2005). Grassmann et al. (2002) emphasized that the compounds identified in the essential oil of terebinth play an active role in the prevention of many diseases such as cancer, Alzheimer's, and so on. They also stated that these substances 
bind types of reactive oxygen by entering the tissues easily with a lipophilic effect and thus show antioxidant properties.

Although it has many functional properties, there is no study regarding the use of terebinth as a functional component in food products. Therefore, this study investigated the effects of using terebinth fruit-which has many positive properties and is generally consumed as coffee and a snack-in cookie formulation as a functional component and particularly on the nutritional quality of cookies.

\section{Materials and methods}

\subsection{Materials}

Wheat flour, powdered sugar, nonfat dry milk, sodium bicarbonate, ammonium bicarbonate, shortening and salt used in the cookie production were obtained from a local market in Kilis, Turkey. High fructose corn syrup was obtained from Beşan Starch Food Industry and Trade Inc. (Gaziantep, Turkey). The terebinth fruit used as an additive in the study was purchased from Şekeroğlu Spice Food Industry and Trade Company.

Cookie production was carried out by adding paste obtained from roasted and unroasted terebinth grains to the flour used in cookie production. Also cookie without terebinth was produced as a control sample. Terebinth grains were cleaned of foreign materials and spoilt grains and were separated into four groups:

a) Group 1 , roasted at $100^{\circ} \mathrm{C}$;

b) Group 2, roasted at $125^{\circ} \mathrm{C}$;

c) Group 3, roasted at $150{ }^{\circ} \mathrm{C}$;

d) Group 4, unroasted.

All groups except Group 4 were roasted in a pre-heated oven (Arçelik brand SUF 4000 MEB model set-top electric oven with temperature and time adjustment) for 20 minutes. Terebinth pastes were obtained by grinding the terebinth in a laboratory-type crushing mill.

\subsection{Methods}

\section{Cookie preparation}

Wire-cut cookies were prepared according to the principles specified in AACC Standard Method No: 10-54.01 (American Association of Cereal Chemists, 2010) by using the basic formula given in Table 1.

Terebinth pastes were added to the cookie formulation by replacing wheat flour with $0 \%$-control, $10 \%, 20 \%, 30 \%, 40 \%$ and $50 \%$ by flour weight. A control sample without terebinth paste was also produced (Table 1). Nonfat dry milk, powdered sugar, salt and shortening were creamed using a KitcheneAid mixer (KSM45 model). HFCS, ammonium bicarbonate and sodium bicarbonate dissolved in water was added to the mixture, and mixed to obtain a homogeneous creamy texture. Finally, flour or flour-terebinth paste mixture was added and mixed in to form cookie dough. The dough was kneaded and sheeted to a uniform thickness of $5 \mathrm{~mm}$ and cut into circular shapes $50 \mathrm{~mm}$
Table 1. Control cookie formulation without terebinth.

\begin{tabular}{lc}
\hline \multicolumn{1}{c}{ Ingredients } & Weight $[\mathrm{g}]$ \\
\hline Powdered sugar & 16.8 \\
Nonfat dry milk & 0.4 \\
Salt & 0.5 \\
Sodium bicarbonate & 0.4 \\
Shortening & 16.0 \\
HFCS (High fructose corn syrup) & 0.6 \\
Ammonium bicarbonate & 0.2 \\
Deionized water; g= (40 - g flour $)+8.8$ & variable \\
Wheat flour & 40 \\
\hline
\end{tabular}

${ }^{\mathrm{a}} 13 \%$ based on humidity.

in diameter. Baking was carried out at $205^{\circ} \mathrm{C}$ for $11 \mathrm{~min}$ in an oven. The cookies were cooled at room temperature and stored in polyethylene bags until further analysis.

The sample names in the text are abbreviated in code names. According to this, unroasted terebinth is shown as A, terebinth roasted at $100^{\circ} \mathrm{C}$ is $\mathrm{B}$, terebinth roasted at $125^{\circ} \mathrm{C}$ is $\mathrm{C}$, and terebinth roasted at $150{ }^{\circ} \mathrm{C}$ is $\mathrm{D}$. Terebinth addition rates are expressed as 1 for $10 \%, 2$ for $20 \%, 3$ for $30 \%, 4$ for $40 \%$ and 5 for $50 \%$.

\section{Chemical analysis}

AACC standard methods were used to determine the ash (method 08-01), protein (method 46-12) and fat (method 30-25) contents of wheat flour, terebinth pastes and cookie samples (American Association of Cereal Chemists, 2010).

\section{Physical analysis}

Diameter $(D)$ and thickness $(T)$ of the cookie samples after baking were measured by using a digital caliper according to AACC Method No: 10-54.01 (American Association of Cereal Chemists, 2010). The spread ratio $(S)$ of cookies was estimated by calculating $D / T$ values.

\section{Functional properties}

\section{Total Dietary Fiber (TDF)}

This analysis was conducted in flour, terebinth pastes, and cookie samples by using a total dietary fiber test kit (Megazyme International Ireland Ltd., Bray Business Park, Bray, Co. Wicklow, Ireland). This method follows the same procedure as the method developed by Lee et al. (1992). Accordingly, after the samples were suspended in $10 \mathrm{~mL}$ of Mes-Tris buffer ( $\mathrm{pH}$ : 8.2), they were treated with thermal $\alpha$-amylase, protease and amyloglucosidase enzymes, respectively, in order to remove starch and proteins. Starch at $100{ }^{\circ} \mathrm{C}$ with thermal $\alpha$-amylase, proteins at $60^{\circ} \mathrm{C}$ with protease were hydrolyzed and the starch was broken down into glucose units at $60^{\circ} \mathrm{C}$ with amyloglucosidase. In order to precipitate the non-starch polysaccharides (dietary fibers) and remove soluble protein and glucose units from the environment, 95\% ethyl alcohol was added to the samples and left for 60 minutes. Later, filtration was performed from glass crucibles with a Por 3 sintered filter. The residue in the flasks was washed again with 
78\% ethyl alcohol, 95\% ethyl alcohol, and acetone, respectively, and filtered again. To determine the total dietary fiber, glass crucibles were dried overnight at $105^{\circ} \mathrm{C}$ and weighed. Later, the content in the glass crucibles was burned at $525^{\circ} \mathrm{C}$ and the ash amount found was removed from the predetermined total dietary fiber and the ash was verified. Then, the total dietary fiber was calculated in dry matter as a percentage.

\section{Phytic acid}

Phytic acid determined in flour, terebinth pastes and cookies was carried out by using Haug \& Lantzsch's (1983) colorimetric method. A fine ground sample was extracted with $0.2 \mathrm{M} \mathrm{HCl}$ for $180 \mathrm{~min}$ in a shaker at $175 \mathrm{rpm}$. After extraction the solutions were centrifuged at $3000 \mathrm{rpm}$ for $20 \mathrm{~min}$ and clear supernatants were used for phytic acid determination. Two milliliters of ferric solution (0.2 g ammonium iron (III) sulphate. $12 \mathrm{H}_{2} \mathrm{O}$ (Merck 3776) was dissolved in $100 \mathrm{~mL} 2 \mathrm{HCI}$ and made up to $1000 \mathrm{~mL}$ with distilled water) was added to $1 \mathrm{~mL}$ of supernatant (containing 3-30 $\mu \mathrm{g} / \mathrm{mL}$ phytate phosphorus) and the solutions were mixed and heated in a boiling water bath for $30 \mathrm{~min}$. The samples taken from the boiling water bath were put into the cold-water bath and cooled to room temperature. After cooling, the samples were centrifuged again for 10 minutes at $3000 \mathrm{rpm}$. One milliliter was taken from the centrifuged samples into glass test tubes and $3 \mathrm{~mL}$ of 2,2 bipyridine solution (10 g of 2,2' bipryridine (Merck 3098) dissolved in $10 \mathrm{~mL}$ of thioglycolic acid (Sigma 528056) in distilled water and made up to $1000 \mathrm{~mL}$ ) was added (after adding bipyridine, the samples appeared pink) to the solution, mixed, and the absorption was measured at $519 \mathrm{~nm}$ against the distilled water. The method was calibrated with the reference solutions as a substitute for the sample solution with each set of analyses. The calibration curve was made using sodium salt of phytic acid (Sigma P-8810). The measurements were performed in duplicate.

\section{Total Phenolic Content (TPC)}

Total phenolic content (TPC) of wheat flour, terebinth paste and cookies was analyzed according to $\mathrm{Yu}$ et al. (2002) with some modification. A one gram sample was extracted with $80 \%$ methanol for two hours at $200 \mathrm{rpm}$ at $37^{\circ} \mathrm{C}$. The TPC of sample extracts were determined using Folin-Ciocalteu reagent. The reaction mixture contained $100 \mu \mathrm{L}$ of sample extracts, $1000 \mu \mathrm{L}$ of the Folin-Ciocalteu reagent, and $2 \mathrm{~mL}$ of $10 \%$ sodium carbonate. After one hour of reaction, the absorbance at $765 \mathrm{~nm}$ was measured. Triplicate reactions were conducted. TPC was calculated with the equation obtained from absorbance/ concentration standard graph previously generated with gallic acid and the results were expressed as the amount of mg gallic acid equivalent (GAE) for a 100 gram sample.

\section{Antioxidant activity}

The modified version of Yu et al's (2002) method was used to analyze wheat flour, terebinth pastes, and cookies. This method is based on the spectrophotometric measurement of the decrease in color resulting from the destruction of DPPH (2,2-diphenyl1-picrylhdrazyl) radical, a pink colored stable compound. $0.1 \mathrm{~g}$ sample was weighed, and then $3 \mathrm{~mL}$ of methyl alcohol was added, and a one-hour extraction was performed. The supernatant part of the tubes, which were centrifuged at $9000 \mathrm{rpm}$ for 20 minutes, was taken into a separate tube and the extract stock was prepared. $3.9 \mathrm{~mL}$ of DPPH solution $(0.025 \mathrm{~g} / \mathrm{L}$ methanol) was mixed with $0.1 \mathrm{~mL}$ of extract and kept at room temperature for 120 minutes. At the end of the period, the sample absorbances were measured at $515 \mathrm{~nm}$. Results were calculated by using Equation 1 as the rate of inhibition percentage of DPPH radical.

DPPH inhibition $(\%)=\left[\left(\mathrm{A}_{\text {Blank }}-\mathrm{A}_{\text {Sample }}\right) / \mathrm{A}_{\text {Blank }}\right] \times 100$

where: $A_{\text {Blank }}=$ Absorbance of blank; $A_{\text {Sample }}=$ Absorbance of sample.

\section{Color analysis}

The color tests for wheat flour, terebinth pastes and cookie samples were conducted by measuring $L^{*}$ (lightness, 100 , white; 0 , black), $\mathrm{a}^{*}\left(+\right.$, red, -, green) and $\mathrm{b}^{*}$ (+, yellow; -, blue) parameters by means of a tristimulus reflectance colorimeter (Hunterlab MiniScan EZ, Reston, Virginia, USA). Color measurements were made in three replicates, and the result was given as the average of these three values.

\section{Textural properties}

Fracture resistance (hardness) analysis of the cookies was performed with the TA-XT2i Texture Analyzer (Stable Micro Systems Ltd., Godalming, Surrey, UK) based on AACC Method No: 74-09.01 (American Association of Cereal Chemists, 2010). For this purpose, the three-point bending test technique (pre-test speed: $1 \mathrm{~mm} / \mathrm{s}$, test speed: $3 \mathrm{~mm} / \mathrm{s}$, post-test speed: $10 \mathrm{~mm} / \mathrm{s}$, test distance: $5 \mathrm{~mm}$, trigger value: $5 \mathrm{~g}$ ) was used. The cookies were placed on two vertical aluminum barriers with a spacing of $4 \mathrm{~cm}$, and a force was applied at a speed of $3 \mathrm{~mm} / \mathrm{s}$ towards their midpoint. The maximum force at the breaking point was recorded as Newton $[\mathrm{N}]$.

\section{Statistical analysis}

The results were compared using analysis of variance (ANOVA) with respect to the terebinth roasting temperature and the terebinth addition rate. Means that were statistically different from each other were compared by using Student's $\mathrm{t}$ comparison test at 5\% confidence interval. JMP 11.0 (SAS Institute Inc., Cary, NC, USA) software was used to perform the statistical analysis.

\section{Results and discussion}

\subsection{Raw material properties}

Some analysis results of wheat flour and terebinth pastes used in cookie formulation are given in Table 2. It was determined that the terebinth pastes had higher ash, protein, fat, TDF, TPC and antioxidant activity values than wheat flour. This condition was found to be statistically significant except for protein $(\mathrm{p}<0.05)$. Therefore, terebinth would be a suitable functional component 
for increasing the nutritional quality of a cookie with its rich chemical composition.

The TDF, TPC, and antioxidant activity values of the terebinth pastes roasted at different temperatures increased with the increase in roasting temperature. The structure and composition of food, the type of heat treatment applied and the degree of temperature can cause an increase in the amount of phenolic components (Sakac et al., 2011). It has been stated that some gallate derivatives convert to gallic acid by the effect of heat. It has been stated that the components in the structure of food, their interaction with each other and phenolic components, and a number of reactions resulting from heat treatment can alter the antioxidant properties and phenolic substance profile of food. In addition, antioxidant activity may increase due to the presence of intermediates occurring by the Maillard reaction (Meral, 2011). As shown in Table 2, roasting caused a decrease in the amount of the phytic acid in the terebinth pastes. The reason for the reduction of phytic acid by heat treatment is due to the effects of temperature on phytic acid and the formation of water insoluble complexes between phytate and other components (Udensi et al., 2007). The ash, protein, fat, phytic acid and total phenolic contents of wheat flour were $0.61 \%, 10.05 \%, 1.15 \%$, $2.48 \mathrm{mg} / \mathrm{g}$ and $0.85 \mathrm{mg} / \mathrm{g}$, respectively. These results are similar to the findings reported by Demir (2015). The ash content of the unroasted terebinth fruit (A) used in the study was determined as $2.40 \%$, the protein content was $10.10 \%$ and the fat content was $38.11 \%$ (Table 2). In a study conducted by Özcan (2004), the ash, protein and fat contents of terebinth fruits were found to be $3.1 \%, 9.67 \%$ and $38.74 \%$, respectively. As may be seen in the table, different roasting temperatures caused a significant increase in all chemical, functional and color characteristics of the terebinth except the ash, protein, and fat $(\mathrm{p}<0.05)$. The amount of ash, protein and fat in terebinths increased with the roasting process. The increase in fat content is thought to be due to the release of fat molecules within the cell by denaturing of the cell wall in the protein structure through the roasting process. The increase in ash and protein values are thought to be caused by a partial increase due to moisture loss. When Table 2 is examined, it may be seen that $L^{*}, a^{*}$ and $b^{*}$ values of wheat flour were $96.56,0.50$, and 8.02 , respectively. The color values of unroasted terebinth fruit $(\mathrm{A})$ were $\mathrm{L}^{\star}=14.79$, $\mathrm{a}^{\star}=4.04$ and $b^{*}=14.27$. When the color values of unroasted terebinth were examined, it was seen that it was more yellow, red, and darker than wheat flour. It was found that color values decreased and, in particular, color darkness increased as the roasting temperature of terebinth samples increased $(\mathrm{p}<0.05)$.

\subsection{Chemical and physical properties of cookies}

The values of some chemical and physical properties of cookies are given in Table 3 . The ash values of the cookies increased significantly with the increase in the terebinth addition ratio at each roasting temperature $(\mathrm{p}<0.05)$.

The ash contents of the cookies varied between $1.37 \%$ and $2.33 \%$. D5 sample had the highest ash values with $2.33 \%$ while the control sample had the lowest ash value with $1.37 \%$. It was observed that the use of terebinth at increasing ratios in cookie formulation significantly increased the amount of protein $(\mathrm{p}<0.05)$.

While the amount of protein was determined as $9.50 \%$ in the control cookies, it ranged between $9.67 \%$ to $10.53 \%$ in the cookies with the terebinth addition. When Table 3 was examined, it was seen that the protein values of the cookie samples with terebinth addition were found to be higher than the control sample. The protein value of the samples increased with both the increase in roasting temperature and the increase in terebinth addition ratio. The increase in protein values was due to the high protein content of the terebinth fruit.

The fat content of terebinth fruit is higher than raw materials such as sunflower seed, olives, cottonseed, soy, safflower and rapeseed which are widely used in oil production. However, it is lower than the fat contents of oily seeds such as peanut, palm, sesame and coconut (Kaya, 2012). Since the fat content in terebinth is higher than the fat content in wheat flour, the fat content in the cookies increased significantly as the terebinth addition ratio increased $(\mathrm{p}<0.05)$ (Table 3$)$. The fat values of the cookies also increased with the increase in the roasting

Table 2. Chemical, physicochemical, functional and color properties of wheat flour and terebinths used in cookie production ${ }^{\dagger}$.

\begin{tabular}{|c|c|c|c|c|c|}
\hline \multirow{2}{*}{ Property } & \multirow{2}{*}{ Wheat flour } & \multicolumn{4}{|c|}{ Terebinth $^{\ddagger}$} \\
\hline & & $\mathrm{A}$ & $\mathrm{B}$ & $\mathrm{C}$ & $\mathrm{D}$ \\
\hline Ash [\%] $]^{\S}$ & $0.61 \pm 0.03^{b}$ & $2.40 \pm 0.01^{\mathrm{a}}$ & $2.44 \pm 0.08^{\mathrm{a}}$ & $2.46 \pm 0.01^{\mathrm{a}}$ & $2.51 \pm 0.06^{\mathrm{a}}$ \\
\hline Protein $[\%]^{\S}$ & $10.05 \pm 0.10^{\mathrm{a}}$ & $10.10 \pm 0.33^{\mathrm{a}}$ & $10.26 \pm 0.11^{\mathrm{a}}$ & $10.41 \pm 0.87^{\mathrm{a}}$ & $10.44 \pm 0.03^{\mathrm{a}}$ \\
\hline Fat $[\%]^{\S}$ & $1.15 \pm 0.18^{\mathrm{d}}$ & $38.11 \pm 0.51^{\mathrm{c}}$ & $39.42 \pm 0.42^{\mathrm{b}}$ & $39.88 \pm 0.08^{\mathrm{b}}$ & $41.57 \pm 0.16^{\mathrm{a}}$ \\
\hline $\mathrm{TDF}[\%]^{\S}$ & $2.13 \pm 0.18^{e}$ & $13.51 \pm 0.21^{\mathrm{d}}$ & $19.70 \pm 0.44^{c}$ & $22.98 \pm 0.59^{b}$ & $24.34 \pm 0.03^{\mathrm{a}}$ \\
\hline TPC $[\mathrm{mg} / \mathrm{g}]$ & $0.85 \pm 0.06^{\mathrm{d}}$ & $11.96 \pm 9.64^{\mathrm{c}}$ & $12.26 \pm 9.64^{\mathrm{b}}$ & $12.49 \pm 3.86^{\mathrm{a}}$ & $12.61 \pm 5.79^{\mathrm{a}}$ \\
\hline $\begin{array}{l}\text { Antioxidant activity } \\
\text { [\% inhibition] }\end{array}$ & $12.54 \pm 0.59^{\mathrm{d}}$ & $92.71 \pm 1.47^{\mathrm{c}}$ & $94.27 \pm 2.21^{\mathrm{bc}}$ & $96.05 \pm 0.59^{\mathrm{ab}}$ & $96.67 \pm 1.18^{\mathrm{a}}$ \\
\hline Phytic acid $[\mathrm{mg} / \mathrm{g}]^{\S}$ & $2.48 \pm 0.16^{\mathrm{b}}$ & $3.48 \pm 0.17^{\mathrm{a}}$ & $2.18 \pm 0.13^{c}$ & $1.23 \pm 0.14^{\mathrm{d}}$ & $0.82 \pm 0.04^{\mathrm{e}}$ \\
\hline$L^{*}$ & $96.56 \pm 0.15^{\mathrm{a}}$ & $14.79 \pm 0.18^{\mathrm{b}}$ & $14.56 \pm 0.13^{\mathrm{b}}$ & $14.50 \pm 0.22^{\mathrm{b}}$ & $12.69 \pm 0.26^{c}$ \\
\hline$a^{*}$ & $0.50 \pm 0.01^{\mathrm{d}}$ & $4.04 \pm 0.00^{c}$ & $6.36 \pm 0.08^{b}$ & $7.92 \pm 0.08^{\mathrm{a}}$ & $7.97 \pm 0.03^{\mathrm{a}}$ \\
\hline$b^{*}$ & $8.02 \pm 0.04^{\mathrm{e}}$ & $14.27 \pm 0.28^{\mathrm{a}}$ & $13.61 \pm 0.21^{\mathrm{b}}$ & $12.82 \pm 0.09^{c}$ & $12.03 \pm 0.02^{\mathrm{d}}$ \\
\hline
\end{tabular}

${ }^{\dagger}$ In the table for terebinth, when the lines are examined from right to left, the values shown with the same letters are not statistically different ( $\left.\mathrm{p}>0.05\right)$; ${ }^{\ddagger}(\mathrm{A})$ Unroasted terebinth; (B) Roasted terebinth at $100^{\circ} \mathrm{C}$; (C) Roasted terebinth at $125^{\circ} \mathrm{C}$; (D) Roasted terebinth at $150{ }^{\circ} \mathrm{C} ;{ }^{\varsigma} \mathrm{Calculated}$ on dry weight basis (dwb); TDF: Total dietary fiber; TPC: Total phenolic content. 
Table 3. Chemical and physical properties of cookies ${ }^{\dagger}$.

\begin{tabular}{|c|c|c|c|c|c|c|}
\hline Samples ${ }^{\ddagger}$ & $\operatorname{Ash}[\%]^{\varsigma}$ & Protein $[\%]^{\varsigma}$ & Fat $[\%]^{\S}$ & $\begin{array}{c}\text { Diameter (D) } \\
{[\mathrm{mm}]}\end{array}$ & $\begin{array}{c}\text { Thickness (T) } \\
{[\mathrm{mm}]}\end{array}$ & Spread ratio $[\mathrm{D} / \mathrm{T}]$ \\
\hline $\mathrm{A} 1$ & $1.37 \pm 0.02^{\mathrm{gh}}$ & $9.67 \pm 0.22^{\mathrm{gh}}$ & $22.92 \pm 1.40^{\mathrm{ef}}$ & $71.10 \pm 0.06^{\text {defg }}$ & $10.70 \pm 1.09^{\mathrm{b}}$ & $6.53 \pm 0.22^{\mathrm{h} 1}$ \\
\hline $\mathrm{A} 3$ & $1.69 \pm 0.02^{\text {cdefgh }}$ & $9.85 \pm 0.01^{\mathrm{fg}}$ & $24.31 \pm 0.74^{\text {bcde }}$ & $72.00 \pm 0.01^{\mathrm{cd}}$ & $9.40 \pm 0.95^{\text {def }}$ & $7.58 \pm 0.10^{\mathrm{ef}}$ \\
\hline A4 & $1.98 \pm 0.15^{\text {abcdef }}$ & $10.05 \pm 0.14^{\text {cdef }}$ & $24.59 \pm 1.82^{\mathrm{bcde}}$ & $72.60 \pm 0.17^{\mathrm{bcd}}$ & $9.00 \pm 0.87^{\mathrm{efg}}$ & $8.36 \pm 0.60^{\mathrm{bcd}}$ \\
\hline B2 & $1.54 \pm 0.03^{\text {eggh }}$ & $9.83 \pm 0.16^{\mathrm{fg}}$ & $24.31 \pm 0.91^{\text {bcde }}$ & $71.70 \pm 0.03^{\text {cde }}$ & $10.00 \pm 0.99^{\mathrm{cd}}$ & $7.28 \pm 0.19^{\mathrm{fg}}$ \\
\hline B3 & $1.72 \pm 0.14^{\text {bcdefgh }}$ & $9.87 \pm 0.05^{\mathrm{efg}}$ & $24.42 \pm 0.83^{\text {bcde }}$ & $71.70 \pm 0.03^{\text {cde }}$ & $9.80 \pm 0.96^{\mathrm{cd}}$ & $7.47 \pm 0.13^{\mathrm{fg}}$ \\
\hline B4 & $2.01 \pm 0.18^{\text {abcde }}$ & $10.27 \pm 0.53^{\mathrm{abcd}}$ & $25.25 \pm 2.98^{\text {bcde }}$ & $72.60 \pm 0.16^{\mathrm{bcd}}$ & $8.70 \pm 0.88^{g}$ & $8.25 \pm 0.31^{c d}$ \\
\hline B5 & $2.15 \pm 0.01^{\mathrm{abc}}$ & $10.40 \pm 0.09^{\mathrm{ab}}$ & $25.98 \pm 1.36^{\mathrm{abcde}}$ & $74.60 \pm 0.21^{\mathrm{a}}$ & $8.50 \pm 0.84^{\mathrm{gh}}$ & $8.88 \pm 0.40^{\mathrm{ab}}$ \\
\hline $\mathrm{C} 1$ & $1.48 \pm 0.14^{\mathrm{fgh}}$ & $9.80 \pm 0.31^{\text {fgh }}$ & $24.73 \pm 1.13^{\mathrm{bcde}}$ & $69.20 \pm 0.06^{\mathrm{gh}}$ & $11.40 \pm 0.03^{\mathrm{b}}$ & $6.07 \pm 0.20^{1}$ \\
\hline D1 & $1.52 \pm 0.08^{\mathrm{efgh}}$ & $9.86 \pm 0.00^{\mathrm{efg}}$ & $25.17 \pm 3.99^{\mathrm{bcde}}$ & $68.40 \pm 0.17^{\mathrm{h}}$ & $12.60 \pm 0.06^{\mathrm{a}}$ & $5.44 \pm 0.38^{j}$ \\
\hline D2 & $1.65 \pm 0.70^{\text {defgh }}$ & $9.95 \pm 0.13^{\text {efg }}$ & $25.48 \pm 0.74^{\text {abcde }}$ & $69.20 \pm 0.03^{\mathrm{gh}}$ & $11.00 \pm 0.03^{\mathrm{b}}$ & $6.29 \pm 0.19^{1}$ \\
\hline D3 & $1.82 \pm 0.36^{\text {bdefg }}$ & $10.05 \pm 0.13^{\text {cdef }}$ & $26.15 \pm 1.32^{\mathrm{abcd}}$ & $69.40 \pm 0.02^{\mathrm{fgh}}$ & $9.90 \pm 0.01^{\mathrm{cd}}$ & $7.01 \pm 0.08^{\mathrm{gh}}$ \\
\hline D4 & $2.21 \pm 0.04^{\mathrm{ab}}$ & $10.40 \pm 0.09^{\mathrm{ab}}$ & $27.14 \pm 1.44^{\mathrm{ab}}$ & $71.90 \pm 0.04^{\mathrm{cd}}$ & $9.50 \pm 0.03^{\mathrm{def}}$ & $7.57 \pm 0.18^{\mathrm{ef}}$ \\
\hline D5 & $2.33 \pm 0.14^{\mathrm{a}}$ & $10.53 \pm 0.09^{\mathrm{a}}$ & $28.50 \pm 0.78^{\mathrm{a}}$ & $73.60 \pm 0.16^{\mathrm{abc}}$ & $8.90 \pm 0.01^{\mathrm{fg}}$ & $8.27 \pm 0.04^{\mathrm{cd}}$ \\
\hline
\end{tabular}

${ }^{\dagger}$ In the table, when the columns are examined from top to bottom, the values shown with the same letters are not statistically different (p $\left.>0.05\right)$; ${ }^{\ddagger}(\mathrm{A})$ Unroasted terebinth added cookie samples; (B) The sample added with roasted terebinth at $100{ }^{\circ} \mathrm{C}$; (C) The sample added with roasted terebinth at $125^{\circ} \mathrm{C}$; (D) The sample added with roasted terebinth at $150{ }^{\circ} \mathrm{C}$; ${ }^{5}$ Calculated on dry weight basis (dwb).

temperature. While the amount of fat in the control cookie was $20.56 \%$, the highest fat content was observed in the D5 sample with a value of $28.50 \%$ in cookies with the terebinth addition. The results are compatible with the results reported by Kaur et al. (2019), Demir (2015), Özbaş et al. (2014) and Uysal et al. (2007).

Diameter, thickness and spread ratio values are important parameters in terms of determining the technological quality of the cookie, and in general, it is desired that the diameter is wide, the spread ratio is high and thickness is low (Demir, 2015). The diameter values of the cookies with the terebinth addition varied between $71.1 \mathrm{~mm}$ and $73.6 \mathrm{~mm}$. While the average diameter values of cookies increased with the increase in the terebinth addition ratio, as the roasting temperature increased, the diameter values decreased (Table 3). The highest diameter value was obtained in the A5 sample $(74.6 \mathrm{~mm})$ and the lowest diameter value $(68.4 \mathrm{~mm})$ was obtained at the cookie sample (D1) with terebinth that was roasted at $150{ }^{\circ} \mathrm{C}$. It was found that the addition of terebinth had a significant effect on the average thickness and spread ratio values of the cookies $(\mathrm{p}<0.05)$. With the addition of terebinth, the spread ratios of cookies increased but their thickness decreased. The spread ratio of cookies is largely dependent on the dough viscosity (Baumgartner et al., 2018). The increased spreading ratio in the cookies with the terebinth addition can be explained with the decrease in dough viscosity. The increase in diameter and spread ratio and the decrease in thickness value were found to be consistent with other studies in the literature (Kaur et al., 2019; Yağc1, 2019; Baumgartner et al., 2018; Bilgiçli et al., 2006). It is also reported in the literature that there is a negative correlation between the spread ratio of the cookies and the protein content of wheat flour (Barak et al., 2013). However, in this study, there was an increase in the spread rates of cookies with an increase in protein contents. This is thought to be due to changes in the gluten structure during cooking. In relation to this situation, Miller et al. (1996) stated that the gluten structure does not occur during dough mixing but forms a continuous network with a visible glass transition during cooking. The spread of the cookie dough stops when this network is sufficient to stop the expansion of the cookie dough. Thus, terebinth might have weakened the gluten structure, leading to an increase in the spread ratio of cookies.

\subsection{Functional properties of cookies}

The total dietary fiber (TDF), total phenolic content (TPC), antioxidant activity (percent inhibition of DPPH radical), and phytic acid values of the cookie samples are shown in Table 4.

The addition of terebinth in both unroasted and roasted forms caused a significant increase in TDF, TPC and antioxidant values of cookies $(p<0.05)$. The reason for this increase is that TDF, TPC and antioxidant levels of both unroasted and roasted terebinth are higher than those of wheat flour (Table 2). TDF, TPC, and antioxidant values of all cookies with the terebinth addition were found to be higher than those of the control cookie. The highest TDF value (17.58\%), TPC value $(5.11 \mathrm{mg} / \mathrm{g})$ and antioxidant value $(33.83 \%)$ of all cookies produced in the study were found in sample D5. The results were found to be consistent with those 
Table 4. Functioal properties of cookies ${ }^{\dagger}$.

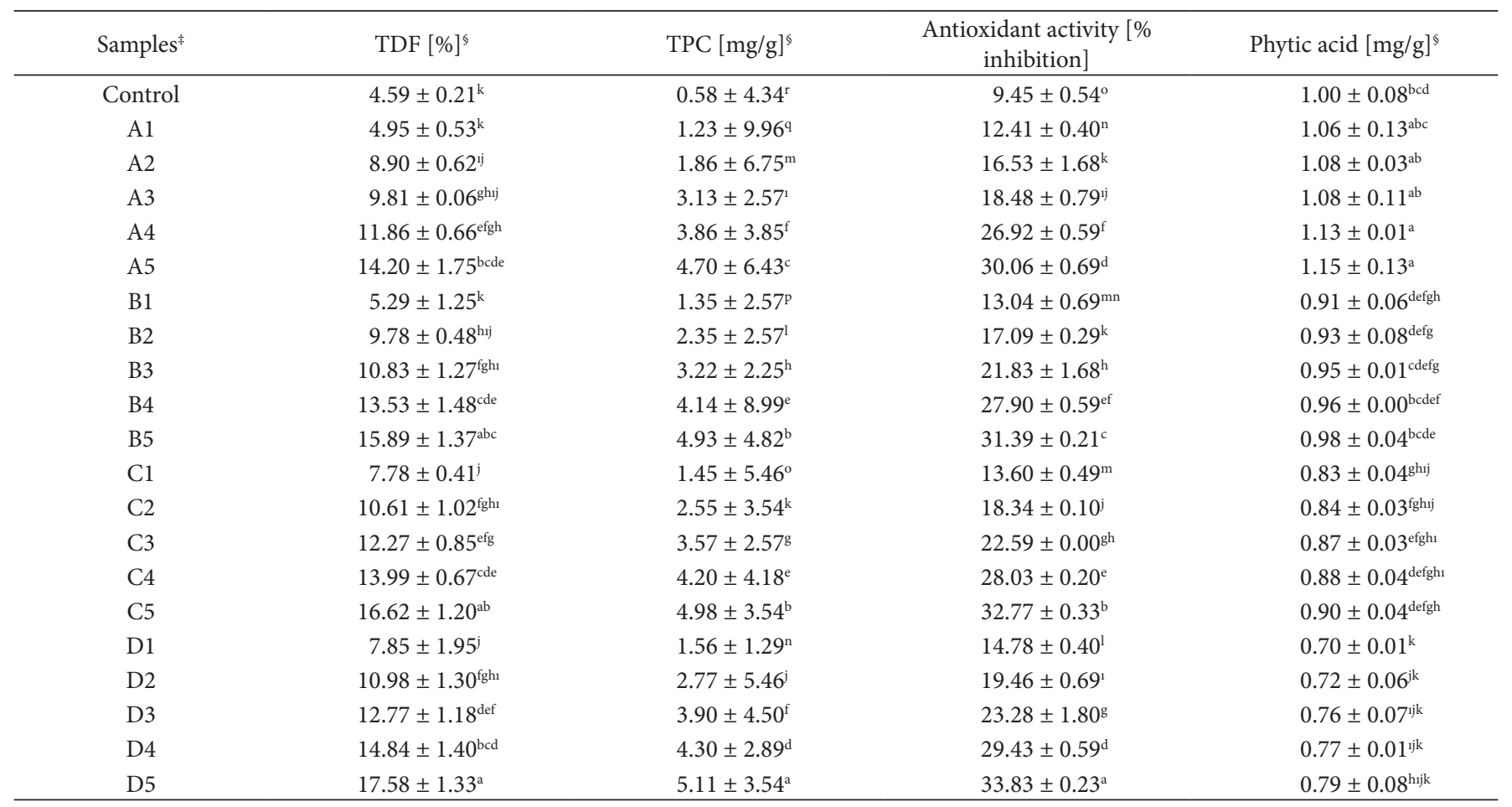

${ }^{\dagger}$ In the table, when the columns are examined from top to bottom, the values shown with the same letters are not statistically different ( $\left.\mathrm{p}>0.05\right)$; ${ }^{\ddagger}(\mathrm{A})$ Unroasted terebinth added cookie samples; (B) The sample added with roasted terebinth at $100^{\circ} \mathrm{C}$; (C) The sample added with roasted terebinth at $125^{\circ} \mathrm{C}$; (D) The sample added with roasted terebinth at $150{ }^{\circ} \mathrm{C} ;{ }^{\circ} \mathrm{Calculated}$ on dry weight basis (dwb); TDF: Total dietary fiber; TPC: Total phenolic content.

reported in previous studies (Kaur et al., 2019; Nakov et al., 2018; Molinari et al., 2017; Konak et al., 2015).

Although phytic acid has important functions for plants, it has some negative effects on the human body. One of the most important of these is that it forms a complex with some essential minerals such as $\mathrm{Ca}, \mathrm{Fe}, \mathrm{Zn}$, and $\mathrm{Mn}$ to prevent their absorption. It can also be effective by binding a large part of the phosphorus as phytate phosphorus in its body or interacting with some amino acids (Zhou \& Erdman, 1995; Dendougui \& Schwedt, 2004; Egli et al., 2004; Hurrell, 2003. From this point of view, it is desirable that the level of phytic acid in food to be low. The addition of terebinth in roasted form caused a decrease in phytic acid value in cookies. The highest amount of phytic acid $(1.15 \mathrm{mg} / \mathrm{g})$ was found in sample A5 while it decreased to $0.79 \mathrm{mg} / \mathrm{g}$ in sample D5. In a study conducted to find the phytate levels, iron content and in vitro usability of the cookies samples with wheat fiber, oat fiber, apple fiber, unilin, soybean flour, amaranth flour and carob flour additions, the cookie samples with carob flour addition were found to have the lowest levels of phytic acid content (5.31 mg/g) (Vitali et al., 2007). Bilgiçli et al. (2005) studied the effect of addition of dietary fiber on the nutritional properties of cookies and found that the phytic acid values of cookies with apple fiber, lemon fiber and wheat fiber addition decreased. They reported that phytic acid values decreased from $2.26 \mathrm{mg} / \mathrm{g}$ to $1.83 \mathrm{mg} / \mathrm{g}$ in the cookies with the apple fiber addition, from $2.19 \mathrm{mg} / \mathrm{g}$ to 1.62 in cookies with the lemon fiber addition, and from $2.22 \mathrm{mg} / \mathrm{g}$ to $1.78 \mathrm{mg} / \mathrm{g}$ in cookies with wheat fiber with the increase in the addition ratio of the fibers.
In this study, the decrease in phytic acid values was thought to be caused by the roasting process applied to the terebinth fruit.

\subsection{Color and textural properties of cookies}

Color is one of the main features affecting the acceptability of cookies by consumers. The color of the cookies is mainly attributed to the Maillard reaction which occurs when the reducing sugars react with the amino groups of proteins in the medium during cooking due to the effect of high temperatures (Hadiyanto et al., 2007). When the color values given in Table 5 are examined, it may be observed that $\mathrm{L}^{*}$ and $\mathrm{b}^{*}$ values of the cookies produced by the terebinth addition decreased, but $a^{*}$ values increased $(p<0.05)$. The highest $L^{*}$ and $b^{*}$ values were observed in the control group sample. In general, the addition of terebinth and the increase in the addition rates caused changes in the color of the end product, resulting in a duller, red color product. Similarly, the roasting process applied to the terebinth also decreased the $\mathrm{L}^{\star}$ and $\mathrm{b}^{*}$ values of the cookies and increased $a^{\star}$ values. The dull and dark color of the cookies can be attributed to terebinth's natural dark color (Table 2). Giuberti et al. (2018) reported that the use of alfalfa seed flour in cookie production affected the end product's color and that darker and less yellow products were obtained. In a similar study, it was found that a values of cookies increased, and $\mathrm{L}$ and $\mathrm{b}$ values decreased after the addition of bulgur bran (Özkeser, 2015). 
Table 5. Color and textural properties of cookies ${ }^{\dagger}$.

\begin{tabular}{|c|c|c|c|c|}
\hline \multirow{2}{*}{ Samples ${ }^{\ddagger}$} & \multicolumn{3}{|c|}{ Color values } & \multirow{2}{*}{$\begin{array}{c}\text { Textural Values } \\
\text { Hardness [N] }\end{array}$} \\
\hline & $\mathrm{L}^{*}$ & $a^{*}$ & $\mathrm{~b}^{*}$ & \\
\hline Control & $52.01 \pm 1.63^{\mathrm{a}}$ & $10.23 \pm 0.16^{\mathrm{a}}$ & $21.91 \pm 1.41^{\mathrm{a}}$ & $27.90 \pm 1.84^{\mathrm{e}}$ \\
\hline $\mathrm{A} 1$ & $39.81 \pm 1.00^{\mathrm{b}}$ & $6.10 \pm 0.68^{1}$ & $13.97 \pm 0.14^{\mathrm{b}}$ & $49.98 \pm 1.64^{\mathrm{a}}$ \\
\hline $\mathrm{A} 2$ & $32.24 \pm 0.49^{\mathrm{e}}$ & $6.74 \pm 0.16^{\mathrm{fgh}}$ & $10.71 \pm 0.55^{\mathrm{d}}$ & $37.19 \pm 0.28^{c}$ \\
\hline $\mathrm{A} 3$ & $30.94 \pm 0.93^{\mathrm{f}}$ & $6.84 \pm 0.07^{\text {efgh }}$ & $9.76 \pm 0.69^{\mathrm{ef}}$ & $30.21 \pm 0.61^{\mathrm{d}}$ \\
\hline A4 & $28.99 \pm 0.44^{\text {ght }}$ & $6.97 \pm 0.06^{\text {bcdef }}$ & $8.34 \pm 0.08^{\mathrm{h}}$ & $16.98 \pm 0.44^{\mathrm{f}}$ \\
\hline B2 & $31.84 \pm 0.65^{\mathrm{ef}}$ & $6.81 \pm 0.21^{\mathrm{efgh}}$ & $10.46 \pm 0.40^{\mathrm{d}}$ & $37.09 \pm 0.06^{c}$ \\
\hline B3 & $29.65 \pm 0.61^{\mathrm{gh}}$ & $6.87 \pm 0.21^{\operatorname{defg}}$ & $9.57 \pm 0.03^{\mathrm{f}}$ & $29.41 \pm 0.61^{\mathrm{de}}$ \\
\hline B4 & $27.22 \pm 0.44^{j}$ & $7.00 \pm 0.03^{\text {bcdef }}$ & $7.58 \pm 0.24^{1}$ & $16.51 \pm 0.47^{\mathrm{f}}$ \\
\hline B5 & $26.47 \pm 0.37^{\mathrm{jk}}$ & $7.05 \pm 0.06^{\text {bcdef }}$ & $6.75 \pm 0.11^{j}$ & $16.39 \pm 0.18^{\mathrm{f}}$ \\
\hline $\mathrm{C} 1$ & $38.21 \pm 0.28^{\mathrm{cd}}$ & $6.60 \pm 0.13^{\mathrm{gh}}$ & $13.42 \pm 0.24^{\mathrm{c}}$ & $48.03 \pm 0.14^{\mathrm{b}}$ \\
\hline $\mathrm{C} 5$ & $25.74 \pm 0.83^{\mathrm{kl}}$ & $7.19 \pm 0.06^{\mathrm{bcd}}$ & $6.27 \pm 0.27^{\mathrm{jk}}$ & $16.19 \pm 0.31^{\mathrm{f}}$ \\
\hline D1 & $37.71 \pm 0.10^{\mathrm{d}}$ & $6.88 \pm 0.17^{\text {cdefg }}$ & $13.28 \pm 0.16^{c}$ & $47.70 \pm 0.31^{\mathrm{b}}$ \\
\hline D2 & $29.82 \pm 0.01^{\mathrm{g}}$ & $6.95 \pm 0.04^{\text {bcdef }}$ & $10.20 \pm 0.07^{\mathrm{de}}$ & $36.03 \pm 0.18^{c}$ \\
\hline D3 & $28.74 \pm 0.45^{\mathrm{h}}$ & $7.08 \pm 0.11^{\text {bcde }}$ & $8.72 \pm 0.04^{\mathrm{gh}}$ & $27.79 \pm 0.98^{\mathrm{e}}$ \\
\hline D4 & $26.44 \pm 0.41^{\mathrm{jk}}$ & $7.20 \pm 0.03^{\mathrm{bc}}$ & $7.37 \pm 0.10^{1}$ & $16.28 \pm 0.30^{\mathrm{f}}$ \\
\hline D5 & $24.94 \pm 0.79^{1}$ & $7.27 \pm 0.06^{\mathrm{b}}$ & $6.15 \pm 0.08^{\mathrm{k}}$ & $15.80 \pm 0.10^{\mathrm{f}}$ \\
\hline
\end{tabular}

${ }^{\dagger}$ In the table, when the columns are examined from top to bottom, the values shown with the same letters are not statistically different ( $\mathrm{p}>0.05$ ); ${ }^{\ddagger}(\mathrm{A})$ Unroasted terebinth added cookie samples; (B) The sample added with roasted terebinth at $100^{\circ} \mathrm{C}$; (C) The sample added with roasted terebinth at $125^{\circ} \mathrm{C}$; (D) The sample added with roasted terebinth at $150{ }^{\circ} \mathrm{C}$.

Textural properties such as hardness and durability defined as the resistance of cookie to deformation are very important parameters in bakery products (Ahlborn et al., 2005). They are also the main parameters affecting consumer acceptance. The hardness measurement values of cookies produced within the study decreased with the increase in the terebinth addition ratio. These decreases were observed especially in the terebinth addition ratios of $30 \%$ or more (Table 5). Pareyt et al. (2008) found that, as the gluten content in cookie dough increased, hardness values decreased due to raising and density changes. The reason for the decrease in the hardness value of the cookies with terebinth addition can be attributed to the decrease in the amount of gluten and the increase in the amount of fat due to terebinth addition. Kaur et al. (2019) reported that the hardness values of cookies with the addition of $10 \%$ and $20 \%$ roasted flaxseed flour were $13.41 \mathrm{~N}$ and $12.01 \mathrm{~N}$, respectively. In another study, it was reported that increasing the burdock root flour addition to the cookie formulation decreased the hardness values of the cookies (Moro et al., 2018).

\section{Conclusions}

In this study, the effect of unroasted and roasted terebinth addition at different temperatures on cookie quality was investigated. Terebinth addition to the cookie formulation increased the functional properties of the samples in terms of ash, protein, fat, dietary fiber, total phenolic content and antioxidant content. All baked formulations indicated a higher browning index as a result of formation of Maillard reaction which results in an increase in antioxidant capacity due to the formation of melanoidins which are extensively known to have antioxidant activity. In conclusion, it was concluded that the use of terebinth in cookie formulation increased the nutritional properties, specifically of total dietary fiber, total phenolic content, and antioxidant activity, and that terebinth could be used as a functional component in cookie enrichment. In subsequent studies, it would be beneficial to further study how storage duration and conditions would affect the quality characteristics and antioxidant potential of terebinth fortified cookies or a related bakery product.

\section{References}

Ahlborn, G. J., Pike, O. A., Hendrix, S. B., Hess, W. M., \& Huber, C. S. (2005). Sensory, mechanical and microscopic evaluation of staling in low-protein and glutenfree breads. Cereal Chemistry, 82(3), 328335. http://dx.doi.org/10.1094/CC-82-0328.

American Association of Cereal Chemists - AACC. (2010). Approved methods of the American Association of Cereal Chemists (11th ed.). St. Paul: AACC.

Bakirel, T., Şener, S., Bakirel, U., Keleş, O., Şennazlı, G., \& Gürel, A. (2003). The investigation of the effects of $P$. Terebinthus L. upon experimentally induced hypercholesterolemia and atherosclerosis in rabbits. Turkish Journal of Veterinary Sciences, 27(6), 1283-1292.

Barak, S., Mudgil, D., \& Singh Khatkar, B. (2013). Effect of composition of gluten proteins and dough rheological properties on the cookiemaking quality. British Food Journal, 115(4), 564-574. http://dx.doi. org/10.1108/00070701311317847. 
Baumgartner, B., Özkaya, B., Saka, I., \& Özkaya, H. (2018). Functional and physical properties of cookies enriched with dephytinized oat bran. Journal of Cereal Science, 80, 24-30. http://dx.doi.org/10.1016/j.jcs.2018.01.011.

Bilgiçli, N., İbanog`lu, S., \& Herken, E. N. (2005). Effect of dietary fibre addition on the selected nutritional properties of cookies. Journal of Food Engineering, 78(1), 86-89. http://dx.doi.org/10.1016/j. jfoodeng.2005.09.009.

Bilgiçli, N., Kara, M., Elgün, A., Ertaş, N., \& Demir, M. K. (2006). Determination of technologic and sensory properties of cookies preparedwith corn flour. Journal of Food Agriculture and Environment, 4(2), 109-111. http://dx.doi.org/10.1234/4.2006.853.

Coşkun, T. (2005). The effects of functional foods on our health. Journal of Child Health and Diseases, 48, 69-84.

Couladis, M., Özcan, M., Tzakou, O., \& Akgül, A. (2003). Compartive essential oil composition of various parts of the turpentine tire (Pistacia Terebintehus L.) growing wild in Turkey. Journal of the Science of Food and Agriculture, 83(2), 136-138. http://dx.doi. org/10.1002/jsfa.1295.

Dalgıç, L., Sermet, S. O., \& Özcan, G. (2011). Effect of roasting temperatures on quality parameters of turpentine oil. Academic Food Journal, 9(3), 26-36.

Demir, M. K. (2015). Utilization of whole wheat flour and its blends in cookies production. Journal of Agricultural Sciences, 21(1), 100-107. http://dx.doi.org/10.15832/tbd.18466.

Demirel, H., \& Demir, M. K. (2018). Farkli turunçgillerden elde edilen albedolarin bisküvi üretiminde kullanimi. The Journal of Food, 43(3), 501-511. http://dx.doi.org/10.15237/gida.GD18021.

Dendougui, F., \& Schwedt, G. (2004). In vitro analysis binding capasities of calcium to phytic acid in different food samples. European Food Research and Technology, 219(4), 409-415. http://dx.doi.org/10.1007/ s00217-004-0912-7.

Doğan, H., \& Meral, R. (2016). The use of Rheum ribes as a functional ingredient in biscuit production. Iğdır University Journal of the Institute of Science \& Technology., 6(4), 91-99. http://dx.doi.org/10.21597/ jist.2016624159.

Edwards, K., Kwaw, I., Matud, J., \& Kurtz, I. (1999). Effect of pistachio nuts on serum lipid levels in patients with moderate hypercholesterolemia. Journal of the American College of Nutrition, 18(3), 229-232. http:// dx.doi.org/10.1080/07315724.1999.10718856. PMid:10376778.

Egli, I., Davidsson, L., Zeder, C., Walczyk, T., \& Hurrell, R. (2004). Dephytinization of a complementary food based on wheat and soy increases zinc, but not copper, apparent absorption in adults. The Journal of Nutrition, 134(5), 1077-1080. http://dx.doi.org/10.1093/ jn/134.5.1077. PMid:15113948.

Giner-Larza, E. M., Manez, S., Recio, M. C., Giner, R. M., Prieto, J. M., Cerda-Nicolas, M., \& Rios, J. L. (2001). Oleanonic acid, a 3-oxotriterpene from Pistacia, inhibits leukotriene synthesis and has anti-inflammatory activity. European Journal of Pharmacology, 428(1), 137-143. http://dx.doi.org/10.1016/S0014-2999(01)01290-0. PMid:11779030.

Giuberti, G., Rocchetti, G., Sigolo, S., Fortunati, P., Lucini, L., \& Gallo, A. (2018). Exploitation of alfalfa seed (Medicago sativa L.) flour into gluten-free rice cookies: nutritional, antioxidant and quality characteristics. Food Chemistry, 239, 679-687. http://dx.doi. org/10.1016/j.foodchem.2017.07.004. PMid:28873621.

Grassmann, J., Hippeli, S., \& Elstner, E. F. (2002). Plant's defence and its benefits for animals and medicine: role of phenolics and terpenoids in avoiding oxygen stress. Plant Physiology and Biochemistry, 40(68), 471-478. http://dx.doi.org/10.1016/S0981-9428(02)01395-5.
Hadiyanto, Asselman, A., Van Straten, G., Boom, R. M., Esveld, D. C., \& Van Boxtel, A. J. B. (2007). Quality prediction of bakery products in the initial phase of process design. Innovative Food Science \& Emerging Technologies, 8(2), 285-298. http://dx.doi.org/10.1016/j. ifset.2007.01.006.

Haug, W., \& Lantzsch, H. J. (1983). Sensitive method for the rapid determination of phytate in cereals and cereal products. Journal of the Science of Food and Agriculture, 34(12), 1423-1426. http:// dx.doi.org/10.1002/jsfa.2740341217.

Hurrell, R. F. (2003). Influence of vegetable protein sources on trace element and mineral bioavailabilty. The Journal of Nutrition, 133(9), 2973-2977. http://dx.doi.org/10.1093/jn/133.9.2973S. PMid:12949395.

Karakaş, B., \& Certel, M. (2004). Mennegiç (Pistacia Terebinthus L.) ağacı meyvesinin (Çitlembik) değerlendirme olanakları. In Proceedings of the Traditional Foods Symposium. Van, Turkey. In Turkish.

Kaur, P., Sharma, P., Kumar, V., Panghal, A., Kaur, J., \& Gat, Y. (2019). Effect of addition of flaxseed flour on phytochemical, physicochemical, nutritional, and textural properties of cookies. Journal of the Saudi Society of Agricultural Sciences, 18(4), 372-377. http://dx.doi. org/10.1016/j.jssas.2017.12.004.

Kaya, F. (2012). Determination of conditions for oil extraction from seeds of terebinth (Master thesis). University of Firat, Turkey.

Kolawole, F. L., Akinwande, B. A., \& Ade-Omowaye, B. I. O. (2018). Physicochemical properties of novel cookies produced from orangefleshed sweet potato cookies enriched with sclerotium of edible mushroom (Pleurotus tuberregium). Journal of the Saudi Society of Agricultural Sciences, 19(2), 174-178. http://dx.doi.org/10.1016/j. jssas.2018.09.001

Konak, Ü. İ., Erem, F., Altındağ, G., \& Certel, M. (2015). Effect of Cherry Laurel (Laurocerasus Officinalis Roem.) incorporation on physical, textural and functional properties of cakes and cookies. Journal of Agricultural Faculty of Uludag University, 29(2), 13-24.

Lee, S. C., Prosky, L., \& Devries, J. W. (1992). Determination of total, soluble, and insoluble dietary fiber in foods-enzymatic-gravimetric method, MES-TRIS buffer: collaborative study. Journal - Association of Official Analytical Chemists, 75, 395-416.

Meral, R. (2011). The effects of natural compounds having functional properties on dough rheologhy and bread (Doctoral thesis). University of Van Yüzüncü Yıl, Turkey.

Miller, R., Mathew, R., \& Hoseney, R. (1996). Use of a thermomechanical analyzer: study of an apparent glass transition in cookie dough. Journal of Thermal Analysis and Calorimetry, 47(5), 1329-1338. http://dx.doi.org/10.1007/BF01992831.

Molinari, R., Costantini, L., Timperio, A. M., Lelli, V., Bonafaccia, F., Bonafaccia, G., \& Merendino, N. (2017). Tartary buckwheat malt as ingredient of gluten-free cookies. Journal of Cereal Science, 80, 37-43. http://dx.doi.org/10.1016/j.jcs.2017.11.011.

Moro, T. M. A., Celegatti, C. M., Pereira, A. P. A., Lopes, A. S., Barbin, D. F., Pastore, G. M., \& Clerici, M. T. P. S. (2018). Use of burdock root flour as a prebiotic ingredient in cookies. Lebensmittel-Wissenschaft + Technologie, 90, 540-546. http://dx.doi.org/10.1016/j.lwt.2017.12.059.

Nakov, G., Brandolini, A., Ivanova, N., Dimov, I., \& Stamatovska, V. (2018). The effect of einkorn (Triticum monococcum L.) whole meal flour addition on physicochemical characteristics, biological active compounds and in vitro starch digestion of cookies. Journal of Cereal Science, 83, 116-122. http://dx.doi.org/10.1016/j.jcs.2018.08.004.

Özbaş, Ö. Ö., Şeker, İ. T., \& Gökbulut, İ. (2014). Effects of apricot kernel flour and fiber-rich fruit powders on low-fat cookie quality. Turkish Journal of Agricultural and Natural Sciences, 1, 1326-1332. Retrieved from https://dergipark.org.tr/tr/pub/turkjans/issue/13310/160907 
Özcan, M. M. (2004). Characteristics of fruit and oil of terebinth (Pistacia terebinthus L.) growing wild in Turkey. Journal of the Science of Food and Agriculture, 84(6), 517-520. http://dx.doi.org/10.1002/jsfa.1632.

Özcan, M. M., Tzakou, O., \& Couladis, M. (2009). Essential oil composition of the turpentine tree (Pistacia terebinthus L.) fruits growing wild in Turkey. Food Chemistry, 114(1), 282-285. http:// dx.doi.org/10.1016/j.foodchem.2008.08.094.

Özçelik, B., Aslan, M., Orhan, I., \& Karaoglu, T. (2005). Antibacterial, antifungal and antiviral activities of the lipophylic extracts of Pistacia vera. Microbiological Research, 160(2), 159-164. http://dx.doi. org/10.1016/j.micres.2004.11.002. PMid:15881833.

Özkeser, İ. (2015). The usage possibilities of bulgur bran as a source of dietary fiber in biscuit (Master thesis). University of Ankara, Turkey.

Pareyt, B., Wilderjans, E., Goesaert, H., Brijs, K., \& Delcour, J. A. (2008). The rol of gluten in sugar-snap cookie system: A model approach based on gluten-starch blends. Journal of Cereal Science, 48(3), 863-869. http://dx.doi.org/10.1016/j.jcs.2008.06.011.

Sakac, M., Torbica, A., Sedej, I., \& Hadnadev, M. (2011). Influence of breadmaking on antioxidant capacity of gluten free breads based on rice and buckwheat flours. Food Research International, 44(9), 2806-2813. http://dx.doi.org/10.1016/j.foodres.2011.06.026.

Topçu, G., Ay, M., Bilici, A., Sarıkürkcü, C., Öztürk, M., \& Ulubelen, A. (2007). A new flavone from antioxidant extracts of Pistacia Terebinthus. Food Chemistry, 103(3), 816-822. http://dx.doi. org/10.1016/j.foodchem.2006.09.028.
Udensi, E. A., Ekwu, F. C., \& Isinguzo, J. N. (2007). Antinutrient factors of vegetable cowpea (Sesquipedalis) seeds during thermal processing. Pakistan Journal of Nutrition, 6(2), 194-197. http:// dx.doi.org/10.3923/pjn.2007.194.197.

Uysal, H., Bilgiçli, N., Elgün, A., İbanoğlu, Ş., Herken, E. N., \& Kürşat Demir, M. (2007). Effect of dietary fibre and xylanase enzyme addition on the selected properties of wire-cut cookies. Journal of Food Engineering, 78(3), 1074-1078. http://dx.doi.org/10.1016/j. jfoodeng.2005.12.019.

Vitali, D., Vedrina Dragojević, I., Šebečić, B., \& Vujić, L. (2007). Impact of modifying tea-biscuit composition on phytate levels and iron content and availability. Food Chemistry, 102(1), 82-89. http://dx.doi. org/10.1016/j.foodchem.2006.05.006.

Yağc1, S. (2019). Rheological properties and biscuit production from flour blends prepared from cereal based by-products. Harran Journal of Agricultural and Food Science, 23(2), 142-149. http:// dx.doi.org/10.29050/harranziraat.410059.

Yu, L., Haley, S., Perret, J., Harris, M., Wilson, J., \& Qian, M. (2002). Free radical scavenging properties of wheat extracts. Journal of Agricultural and Food Chemistry, 50(6), 1619-1624. http://dx.doi. org/10.1021/jf010964p. PMid:11879046.

Zhou, J. R., \& Erdman, J. W. Jr. (1995). Phytic acid in health and disease. Critical Reviews in Food Science and Nutrition, 35(6), 495-508. http:// dx.doi.org/10.1080/10408399509527712. PMid:8777015. 